\title{
Tributes to the late John Mason
}

John was a wonderful guy, high-energy, committed, driven, super-smart... and a great friend. He gave me my first real break in the world of nutrition. I vividly recall him showing up at the London School in 1989 to "interview" me. Half the conversation was spent with him hanging out of the window, smoking his pipe. I got the job at the SCN and drove down two days later in a broken-down VW. A 3-week consultancy became 4.5 years, during which time I learnt so much from John. He was 100\% all the time. too hands-on to be a true coordinator...but a real dynamo. He didn't suffer fools, but was so generous with his time and support for everyone who showed true commitment. Under his watch the World Nutrition Report series started in the late 80s, and a raft of nutrition policy papers that broke new ground. A huge contribution from a larger than life personality who will be greatly missed.

Stuart Gillespie International Food Policy Research Institute

I'm heartbroken. I was John's student, mentee, and colleague over 20 years. He was unique in his contributions to public health nutrition and a most special person to encounter--there is no one like him. I was incredibly lucky that I got to have him as a professor in 1998 and then came back to work alongside him from 2012. I remember meeting him as a bright eyed, naïve student ready to change the world, and then many years later as a (slightly more jaded) member of faculty. His devotion to solving nutrition problems never waned, which was so inspirational, like how his eyes sparkled when he talked about exciting new ideas, and how to make life better for people at the margins--what a wonderful smile and easy demeanor. He was so kind to students, cared about doing things fairly, and justice in all matters, always deeply respectful to the work. I learned more from him than from anyone, and saw how he was an advocate for those who didn't feel comfortable to speak up, very gentle and wise. As I go forward, I hope to become as good a mentor as he was to me. I hope this can be included in his tribute.

Alessandra Bazzano

Tulane University

I first met John in the 1960s when I was in the Nutrition Branch of the Ministry of Agriculture, Fisheries and Food in London, and John came to see us with his PhD supervisor, Dr Kodicek, from Cambridge. Years later I got to know him well through the SCN, and he became a good friend and colleague whom I greatly admired and respected. His insistence on including refugees as a distinct group in his assessments of nutritional status was typical of his principles. He had enormous energy and capacity for hard work, and for enjoyment of life.

\section{Peter Greaves}

Former head of nutrition at UNICEF 
Thank you for sad news about late John Mason. Please forward my condolence to John's family. I feel sad about that. John had contributed significantly in helping me to put nutrition in the national development agenda in late 1980s and early 1990s, especially on the development of Food and Nutrition Surveillance in Indonesia with Cornell team under Prof JP Habicht. John and Prof Latham, had also supported me to participate at ACC/SCN until mid-1990s. Among others he supported the publication of my report on "Economic Growth, Equity and Nutrition Improvement in Indonesia" in UN-ACC/SCN publication 1993 with foreword by Dr. A.Horwitz, Chairman ACC/SCN.

\section{Soekirman}

Prof.(Em)Soekirman, SKM, MPS,PhD / Bogor Agricultural University (IPB),Bogor, Indonesia/Founder and Executive Director of the Indonesia Nutrition Foundation for Food Fortification (KFI),Jakarta,Indonesia

To add to Soekirman's comments, with John Mason running the staff and Abraham Horwitz as head of the ACC/SCN, it was at its most impactful period globally. John during that period worked with Abraham Horwitz to have the ACC/SCN be a major instrument of global funding, new initiatives, cross agency linkages - the likes of which we had never seen up until then. It was the most integrated period for international bilateral and multilateral agencies working together on undernutrition and the origin of many initiatives and issues ignored before then.

\section{Barry Popkin}

University of North Carolina

I met John when he came to Cornell in 1980 and was quite impressed by his work there on nutrition surveillance. And how impressed I was by his skills and commitment only increased over the years. His intellect and drive resulted in achievements in our field hard to believe one person could do in a lifetime. He was the Executive Secretary of the SCN annual meetings when I starting attending them in 1987 and I was delighted with the progress made under his leadership as I attended from year to year. Indeed, that was the golden age of the SCN, both highly productive and increasingly democratic, bringing together UN agencies, bilaterals, and NGOs/Civil Society. He asked me to be the first Chair of the Bilateral constituency of the SCN in 1990 and we worked well together while I did that during the next five years--and had some nice talks in the evenings during the meetings. With a team of others, we have worked together closely for the past several years on papers related to the need to phase out megadose vitamin A capsule distribution, but the most creative and scientific parts came from him. After Michael Latham's death, John became a kind of mentor for me and will always have a special place in my heart.

Ted Greiner

Editor, World Nutrition 
John's cross-disciplinary reach was hugely important in helping all of us engage the many reasons nutrition programs and policies did not necessarily produce expected results. He was always generous with his timely responses to requests for information, and sharing his data and analyses, published and unpublished. Some kind of festschrift in his honor would be a productive opportunity to honor his legacy, take stock of questions he raised in various contexts, and move forward.

\section{Ellen Messer}

Tufts University

John brought tremendous energy to his work at the ACC/SCN and Tulane.He started the periodic examinations of the world nutrition situation, just one of many, many indications of the impact that he had through his position as SCN technical secretary as Soekirman and Barry have described. He leaves us with a legacy of substantial achievements to advance our field and, for all who worked with him, fondness, appreciation for his kindness, and lots of amusing stories.

\section{Ed Frongillo \\ University of South Carolina}

We all appreciate what John had done for nutrition. John was also a good friend and helpful colleague to many of us over the years. He was kind and generous and supportive of our needs. One could yell at him and he would say at the end "are we still friends?" And of course the friendship never stopped. He was a very family-oriented person; for example, he cancelled a trip to an important conference in India as hurricane Katrina was nearing New Orleans but e-mailed his presentation. He'll be sorely missed.

Judit Katona-Apte, Bangkok

This is very sad news. My thoughts are with his wife. I met John only once during the last symposium of the WPHNA in South Africa during which four "generations" of UNSCN coordinators met.

John Mason has been secretary of UNSCN during a decade and at the office we are still reaping the fruits of the work he has done. If you agree we will also publish your obituary, in our upcoming UNSCN update.

Stineke Oenema

UNSCN Coordinator

Very sad to hear that John Mason has passed away. I knew him briefly soon after leaving Cornell in 1978 when I joined IFPRI, and he was in FAO. He was so forward looking and was actively pioneering more integral connections between agricultural policy/practice and 
nutritional outcomes. It was a terrific learning experience for me when he launched me into the middle of Zambia's Third National Development Plan to work with its Ministry of Agriculture to get nutrition language integrated into this Plan. This engagement was also very helpful in getting IFPRI's nutrition effort a firm footing in ground realities, and led to a series of collaborative efforts in nutrition that continued long after John had left FAO. I lost touch with him after that, but it was great working with him, and in the recollections that are being shared, I am happy to hear more about his enormous contributions that he continued to make.

Thank you, John for all you done to make the world a better place. May your soul rest in peace.

Shubh Kumar-Range

Core Group Member, Evaluation Community of India and Founder Member, Community of Evaluators South Asia

Thanks for letting us know of John Mason's passing. His contribution to nutrition surveillance in our part of the world through the Joint UNICEF/ Cornell University 6 weeks nutrition surveillance course he conducted, was enormous. I had the privilege of spending 6 weeks in Zomba Malawi in 1986, being oriented/drilled on nutrition surveillance by him. The one take home message I have never forgotten from that training was that 'if the data you are collecting as part of your surveillance system, cannot be acted upon where it is being collected, to improve the situation, or change direction, then it is just being collected for historical purposes, and that is NOT surveillance! You may therefore need to reconsider the indicator you are collecting!'.

I later had the pleasure of working with him when John was the Executive Secretary to the SCN, and I was a member of the Advisory Group for Nutrition for the SCN. His forthright manner was not always everyone's cup of tea but I admired and respected it. He helped to steer the SCN though some of its most turbulent times under the leadership of the late Dr. Horwitz the then SCN Chair.

John Mason has left a rich legacy, may his family draw some comfort in knowing that he touched so many lives across the globe, in a very positive way. May his soul rest in eternal peace.

Julia Tagwireyi

It is sad to learn of John's passing! I met John Mason when he was with Cornell Food and Nutrition Policy Program in the early 1980s. He was always warm and approachable. Please forward my condolences to his family.

Godwin Ndossi 